\title{
Fumigant toxicity of some essential oils against Red Flour Beetles, Tribolium castaneum (Herbst) and its safety to mammals
}

\author{
T. M. Sileem ${ }^{a}$ (D), A. L. Mehany ${ }^{b}$ (D) and R. S. Hassan ${ }^{a *}$ (D) \\ aBiological Application Department, Nuclear Research Center, Atomic Energy Authority, P.O. Box 13759, Abo-Zaabal, Egypt \\ bPlant Research Department, Nuclear Research Center, Atomic Energy Authority, P.O. Box 13759, Abo-Zaabal, Egypt \\ *e-mail: Redahassan424@gmail.com
}

Received: February 5, 2019 - Accepted: May 31, 2019 - Distributed: November 30, 2020

(With 9 figures)

\begin{abstract}
Fumigant activities for three essential oils; Garlic oil (Allium sativum L); Chili pepper (Capsicum annuum L.) and Nigella (Nigella sativa L.) were assessed at different concentrations against the adult and 20-days old larval stages of Tribolium castaneum (Herbst) (Coleoptera: Tenebrionidae) in the laboratory. The accumulative mortality was observed at different exposure periods $(3,5$ and 7 days). The residual effect of garlic oil that was the effective oil, on the treated wheat grains was evaluated with respect to histological changes in the liver, kidney, and stomach of rat fed on this treated wheat. The results showed that the mortality rates of treated stages increased with increasing the time of fumigation treatment. Moreover the highest essential oils toxicity at the Median lethal concentration $\left(\mathrm{LC}_{50}\right)$ values for exposure periods ( 3,5 and 7 days) to fumigation were $(126,53$, and $47 \mathrm{mg} / \mathrm{L}$ air) for adult stage and were $(79,62$, and $41 \mathrm{mg} / \mathrm{L}$ air) for larval stage, respectively in the case of Garlic oil treatment. While, the lowest essential oils effective was Nigella oil at the Median lethal concentration $\left(\mathrm{LC}_{50}\right)$ values for exposure periods ( 3,5 and 7 days) to fumigation were $(3594,629$, and $335 \mathrm{mg} / \mathrm{L}$ air) for adult stage and were $(1040,416$, and $227 \mathrm{mg} / \mathrm{L}$ air) for larval stage, respectively. The toxicity effect of various essential oils against adults and larvae of $T$. castaneum at the $\mathrm{LC}_{50}$ at 7 days fumigation could be arranged in descending order as follows: Garlic oil, Chili pepper oil, and Nigella oil. The histological changes showed that the organs slightly affected at the fumigation for 3 days. It may be concluded that the garlic essential oil is the good effective fumigant to control T. castaneum in the stored products and it recommended that the fumigation period does not exceed 3 days. The garlic essential oil has the potential for applications in IPM programs for stored-grain pests because of its high volatility and fumigant activity and its safety.
\end{abstract}

Keywords: stored grains, essential oils, fumigation, Tribolium castaneum.

\section{Toxidade fumigante de alguns óleos essenciais contra besouros de farinha vermelha, Tribolium castaneum (Herbst) e sua segurança para mamíferos}

\begin{abstract}
Resumo
Atividades fumigantes de três óleos essenciais - óleo de alho (Allium sativum L.); pimenta-malagueta (Capsicum annuum L.) e Nigella (Nigella sativa L.) - foram avaliadas em diferentes concentrações contra adultos e larvas de Tribolium castaneum (Herbst) (Coleoptera: Tenebrionidae) com 20 dias de idade em laboratório. A mortalidade acumulada foi observada em diferentes períodos de exposição (3, 5 e 7 dias). O efeito residual do óleo de alho, ou seja, o óleo eficaz, nos grãos de trigo tratados foi avaliado em relação às alterações histológicas no fígado, rim e estômago de ratos alimentados com esse trigo tratado. Os resultados mostraram que as taxas de mortalidade dos estágios tratados cresceram com o aumento do tempo de exposição ao tratamento de fumigação. A maior toxidade dos óleos essenciais nos valores de Concentração Letal Média $\left(\mathrm{CL}_{50}\right)$ para os períodos de exposição (3, 5 e 7 dias) à fumigação foi (126, 53 e $47 \mathrm{mg} / \mathrm{L}$ ar) para a fase adulta e $(79,62$ e $41 \mathrm{mg} / \mathrm{L}$ ar) para a fase de larva, respectivamente no caso do tratamento com o óleo de alho, enquanto que o óleo essencial menos eficaze foi o óleo de Nigella, com valores de $\mathrm{CL}_{50}$ para os períodos de exposição (3, 5 e 7 dias) à fumigação $(3594,629$ e $335 \mathrm{mg} / \mathrm{L}$ ar) para a fase adulta, e (1040, 416 e $227 \mathrm{mg} / \mathrm{L}$ ar) para a fase de larva, respectivamente. O efeito da toxidade de vários óleos essenciais contra adultos e larvas de T. castaneum em $\mathrm{LC}_{50}$ aos sete dias de fumigação pôde ser organizado em ordem decrescente, como segue: óleo de alho, óleo de pimenta e óleo de Nigella. As alterações histológicas mostraram que os órgãos foram levemente afetados na fumigação por três dias. Pode-se concluir que o óleo essencial de alho é um bom fumigante efetivo no controle de T. castaneum nos produtos armazenados, e recomendou-se que o período de fumigação não ultrapassasse três dias. O óleo essencial de alho tem potencial para aplicações em programas de Integrated Pests Management (IPM) para pragas de grãos armazenados, devido à sua alta volatilidade, atividade fumigante e respectiva segurança.
\end{abstract}

Palavras-chave: grãos armazenados, óleos essenciais, fumigação, Tribolium castaneum.

Braz. J. Biol., 2020, vol. 80, no. 4 pp.769-776 


\section{Introduction}

Insect pests of stored products are responsible for considerable economic losses to stored grains. Tribolium castaneum (Herbts) (Coleoptera: Tenebrionidae) is an important pest of stored grains in Egypt. It presents secondary eating habits and is cosmopolitan, can attack different products, as like flour, bran, feed, grain, biscuits, etc. (Trematerra and Sciarretta, 2004; Daglish, 2006). Control of this insect relies heavily on the use of synthetic insecticides and fumigants, which has led to problems to the environment. This included, increasing costs of application, pest resurgence, pest resistance to insecticides and lethal effects on non-target organisms in addition to direct toxicity to users (Muniz et al., 2008; Boyer et al., 2012; Darwish et al., 2015; El-Gizawy, 2012). Nowadays, the plants are tested in the form of powder, vegetable oil; essential oil (EO), aqueous and organic extracts in the laboratories aginst the insect pests (Boeke et al., 2004). There are several scientific reports that describe various biological effects which include toxic, repellent and anti-feeding effects (Jacobson, 1990; Koul et al., 2008; Mossa, 2016).

Much effort has, therefore, been focused on plant-derived materials for potentially useful products as commercial insectcontrol agents. Although many studies have addressed the potential toxicity of essential oils as protectants for stored products, the residue effect studies of some of them are still required. Therefore, the present study was conducted to evaluate the effect of the toxicity of some essential oils against the two stages of T. castaneum and identify the impact of effective once which exhibits residue on treated wheat on histological changes in some rat organs.

\section{Material and Methods}

\subsection{Insect culture}

Tribolium castaneum was reared in glass containers $(250 \mathrm{~mL})$ containing wheat flour covered with a fine mesh cloth for ventilation. The cultures were maintained in the dark in an incubator at $28 \pm 2{ }^{\circ} \mathrm{C}$ and $60 \pm 5 \% \mathrm{RH}$ (Ayvaz et al., 2002). Adults were obtained from laboratory stock cultures maintained at the Plant Protection Dept. Faculty of Agric., Moshtohor, Benha University, Egypt.

\subsection{Essential oils}

Three essential oils belonging to different families; Amaryllidaceae, Solanaceae; and Ranunculaceae were used in this study. All the essential oils were bought from Al-Gomhuria Company of drugs, chemicals, and medical supplies in Egypt. The used oils were Garlic oil (Allium sativum L); Chili pepper (Capsicum annuum L.); and Nigella (Nigella sativa L.) The fumigant toxicity of these oils was tested to the 7-days old adults and 20-days old larvae of $T$. castaneum at $28 \pm 2{ }^{\circ} \mathrm{C}$ and $60 \pm 5 \% \mathrm{RH}$.

\subsection{Fumigant toxicity of essential oils against the insect pest stages}

Ten grams from each pure oil were diluted with $50 \mathrm{~mL}$ acetone to obtain $20 \%$ (w/v) stock solution which was diluted to obtain $0.625,1.25,2.5,5$, and $10 \%(\mathrm{w} / \mathrm{v})$ concentrations. In this experiment, $200 \mathrm{ml}$ glass jars with tinted covers were used as fumigation chambers for the plant oil. The tested dosages of oil inside the jars were $62.5,125,250,500$, and $1000 \mathrm{mg} / \mathrm{L}$ air. Tested essential oils on mentioned concentrations were applied on filter paper individually and were inserted at the bottom of the jars. For every jar, one filter paper was inserted at the bottom and six jars were used in each treatment. Thirty adults or larvae were put inside each jar in cotton bags $(2 \times 1 \mathrm{~cm})$ with a few amounts of crushed wheat. The jars well closed and incubated at $27 \pm 2{ }^{\circ} \mathrm{C}$ and $65 \pm 5 \%$ R.H. Three replicates (30 larva or adults per replicate) were used for each treatment and control, thus we thought that this numbers are enough to make block based experimental design. The same steps were followed in the control treatment using only acetone without oil. The mortality of larvae and/or adults was calculated for the exposure times 3, 5, and 7 days after fumigation treatment. The insect mortality data was corrected by Abbott's (1925) formula.

\subsection{Histological study}

Twenty-seven male Albino Wister rats, weighing $150 \pm 25 \mathrm{~g}$ were obtained from Rodents laboratory at Faculty of Agriculture, Moshtohor, Benha University. Experimental design and animal handling were approved by the Research Ethical Committee of Faculty of Veterinary Medicine, Benha University, Egypt. All efforts were made to minimize animal suffering. After one week acclimation period, rats were randomly assigned to three groups; the first group fed on fumigant grain with the $\mathrm{LC}_{50}$ of garlic oil, at exposure time 3 days and the other at exposure time 5 days while the third fed on untreated grain as a control. Three replicates were carried out for each group. Specimens from vital organs (liver, kidney, and stomach) of treated male rats were collected at $3^{\text {rd }}$ and $5^{\text {th }}$ days after treatment. Specimens from these organs were taken at the same exposure times from control rats for comparison. All specimens were fixed in 10\% neutral buffered formalin and were dehydrated in ascending grades of ethyl alcohol, cleared in xylene, blocked in paraffin. Paraffin blocks were cut in sections of 5-micron thickness. Sections were stained with Hematoxylin and Eosin for general structure, periodic acid Schiff method for glycogen detection, and Masson's trichrome for identification of collagen fibers according to the method described by Daneshbakhsh et al. (2018). All histological changes were examined and photographed by Leica microscope.

\subsection{Statistical analysis}

The obtained mortality data were subjected to Probit analysis Finney (1971), using a computer program of Noack and Reichmuth (1978).

\section{Results and Discussion}

\subsection{Fumigant toxicity of different essential oils against the stages of Tribolium castaneum}

The effect of the three plant oils Garlic oil (Allium sativum), Chili pepper oil (Capsicum annuum), and Nigella oil (Nigella sativa), on T. castaneum was summarized in Table 1. The probit statistics estimates of sublethal concentrations and their $95 \%$ confidence limits and the 


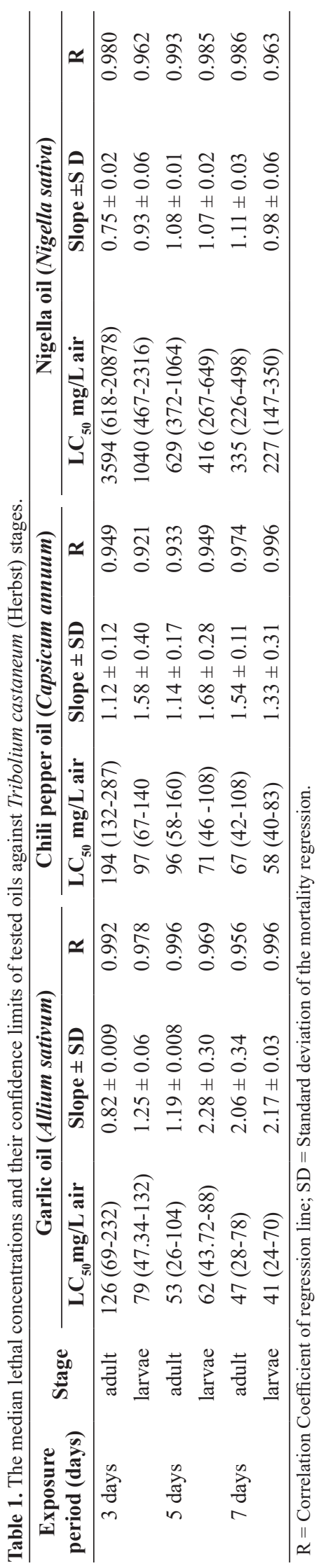


slopes of regression lines. The results showed that the median lethal concentration $\left(\mathrm{LC}_{50}\right)$ value for Garlic oil at exposure time 3 days for the adult stage was $126 \mathrm{mg} / \mathrm{L}$ air, while this corresponding value at 7 days was significantly lower and amounted to $47 \mathrm{mg} / \mathrm{L}$ air. The same table cleared that the $\mathrm{LC}_{50}$ value for 20 -days old larvae was $79 \mathrm{mg} / \mathrm{L}$ air, while this corresponding value at 7 days post-treatment was significantly lower and amounted to $41 \mathrm{mg} / \mathrm{L}$ air for the same oil. There was a clear difference between the top and bottom rate with overlapping $95 \%$ confidence interval (CI). The highest $\mathrm{LC}_{50}$ for a treated adult stage with Chili pepper essential oil was $194 \mathrm{mg} / \mathrm{L}$ air at exposure time 3 days which was reduced gradually to $67 \mathrm{mg} / \mathrm{L}$ air at exposure time 7 days as shown in Table 1. Where, the $\mathrm{LC}_{50}$ at 3-day treatment was 3 times higher than the $\mathrm{LC}_{50}$ at 7 days after treatment. The median lethal concentrations of Nigella essential oil to adult and 20-day old larvae of T. castaneum as shown in Table 1 showed that the lethal concentrations are exposure period dependent. The higher exposure period corresponded to $335 \mathrm{mg} / \mathrm{L}$ air, the lower the LC values. At 3 days exposure time for the adult stage, the $\mathrm{LC}_{50}$ value was $3594 \mathrm{mg} / \mathrm{L}$ air. The corresponding value at 7 days exposure time was significantly lower and amounted to $335 \mathrm{mg} / \mathrm{L}$ air. While 20-days old larvae, the $\mathrm{LC}_{50}$ value was $1040 \mathrm{mg} / \mathrm{L}$ air. The corresponding value at 7 days exposure time was significantly lower and amounted $227 \mathrm{mg} / \mathrm{L}$ air for the mentioned oil. This means that the $\mathrm{LC}_{50}$ at 3 days exposure time treatment was 10 times higher than the $\mathrm{LC}_{50}$ at 7 day exposure time treatment for treated adult and 4.5 times for treated larvae. The plant essential oil was highly toxic to the $T$. castaneum larvae $\left(\mathrm{LC}_{50}=79,62\right.$, and $41 \mathrm{mg} / \mathrm{L}$ air at 3, 5, and 7days exposure times treatment respectively,) for Garlic oil, the slope values ranged between 1.25-2.17. Although the Garlic oil was effective than the Chili pepper oil, regression (probit) analysis showed that both oils had insecticidal potential against $T$. castaneum stages (Table 1).

\subsection{Relative toxicity of essential oils against stages of Tribolium castaneum}

The toxicity effect of various essential oils against adults and larvae of $T$. castaneum at the $\mathrm{LC}_{50}$ and $\mathrm{LC}_{95}$ at 7 days exposure period could be arranged in descending order as follows: Garlic oil, Chili pepper oil and Nigella oil which was the least effective (Table 2). The results indicated also that Garlic oils were much more effective as fumigants against $T$. castaneum adult more than against the larvae. For both adults and larval stages the toxicities of Chili pepper oil was similar to that of Garlic oil, while, Nigella oil was shown a much lower level of activity. The relative toxicity was up to 18.3 , and $3.0 \%$ at the $\mathrm{LC}_{50}$ and $\mathrm{LC}_{95}$ values respectively, for adult stage While it was 14.1 , and $2.3 \%$ at the $\mathrm{LC}_{50}$ and $\mathrm{LC}_{95}$ values respectively for larvae stage when compared with Garlic oil (100\%). Our results on fumigant toxicity of Allium sativum and Capsicum annuum on Tribolium castaneum (Herbst) larval and adult stages indicated that these essential oils had good fumigation toxicity.. These findings relate with Mobki et al. (2014) who reported that mortality of $T$. castaneum increased with increasing garlic extract with concentration and time. The concentration of $225.8 \mu \mathrm{l} / \mathrm{l}$ air of the garlic extract generated $83.3 \%$ larval mortality after 48 hours. The current findings are in partial resemblance with the results obtained by Huang et al. (2000) who stated that the contact and fumigant toxicities of compounds extracted from garlic, A. sativum were greater against the adults. These two compounds (methyl allyl disulfide and diallyltrisulfide) of garlic were also more toxic to T. castaneum adults than to $S$. zeamais. Mona et al. (2009) reported similar results that garlic (A. sativum), mint (Mentha piperita), basil (Ocimum basilicum), thyme (Thymus vulgaris), sesame (Sesamum vindicume) and chamomile (Chamaemelum nobile) plant extracts showed both toxicity and repellency actions against $T$. castaneum.

\subsection{Histological studies of the effect of $L C_{50}$ garlic oil on some rat organs}

\subsubsection{Liver}

The histological examination of liver tissues in rats fed on fumigant or non-fumigant wheat grains were presented in Figures 1-3. The control animals showed a normal histological structure and, minimal fatty change but no liver cell degeneration (Figure 1). Compared to the liver of rats of the control group, the animals' group was tested after feeding on the wheat fumigated for 3 days, the liver tissues showed slight histological changes. In these liver tissues, some hepatocytes appeared as fat cells of empty cytoplasm with peripheral nuclei while the other hepatocytes showed normal histological features (Figure 2).

Table 2. Toxicity index of various essential oils against the Tribolium castaneum (Herbst) stages for fumigation period at 7 days.

\begin{tabular}{|c|c|c|c|c|c|c|c|}
\hline \multirow{2}{*}{ Insect pest stage } & \multirow{2}{*}{ Essential oils } & \multirow{2}{*}{$\mathrm{LC}_{50} \mathrm{mg} / \mathrm{L}$ air } & \multirow{2}{*}{$\mathrm{LC}_{95} \mathrm{mg} / \mathrm{L}$ air } & \multicolumn{2}{|c|}{ Relative toxicity at } & \multicolumn{2}{|c|}{ Folds } \\
\hline & & & & $\mathrm{LC}_{50}$ & $\mathrm{LC}_{95}$ & $\mathrm{LC}_{50}$ & $\mathrm{LC}_{95}$ \\
\hline \multirow[t]{3}{*}{ Adult } & Garlic oil & 41.7 & 297 & 100.0 & 100 & 5.5 & 33.4 \\
\hline & Chili pepper oil & 58.4 & 783 & 71.4 & 37.9 & 3.9 & 12.7 \\
\hline & Nigella oil & 227.8 & 9918 & 18.3 & 3.0 & 1 & 1 \\
\hline \multirow[t]{3}{*}{ 20-days old larvae } & Garlic oil & 47.5 & 238 & 100.0 & 100 & 7.1 & 43.7 \\
\hline & Chili pepper oil & 67.9 & 276 & 70.0 & 86.2 & 4.9 & 37.4 \\
\hline & Nigella oil & 336.0 & 10394 & 14.1 & 2.3 & 1 & 1 \\
\hline
\end{tabular}

The relative toxicity was calculated as [(the least $\mathrm{LC}_{50}$ value $) /\left(\mathrm{LC}_{50}\right.$ value of other oils $\left.)\right] \times 100$. 


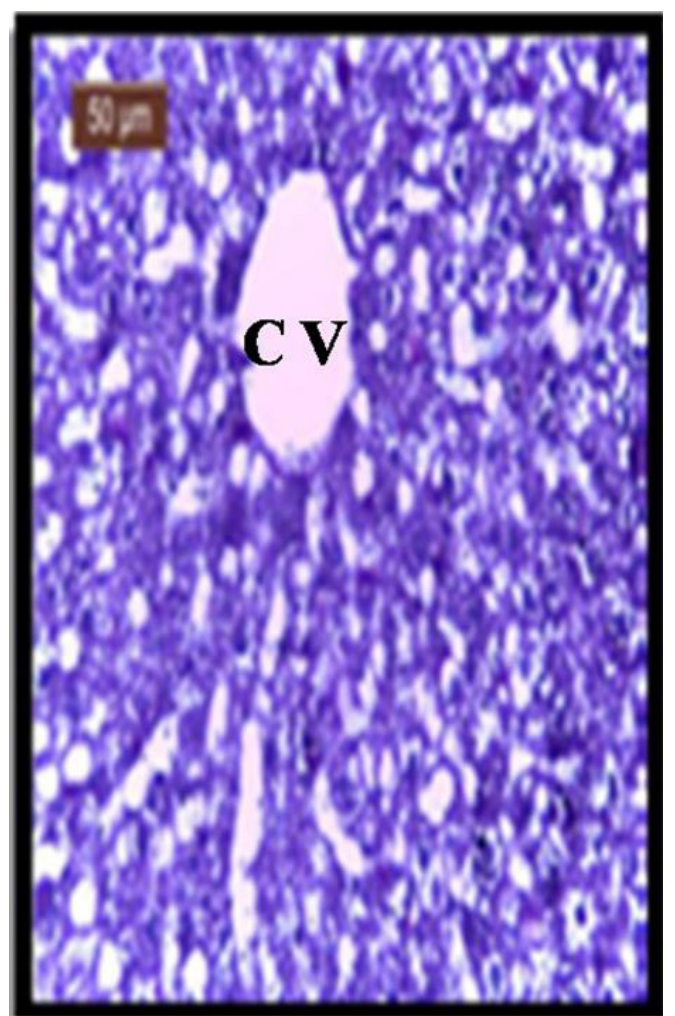

Figure 1. Photomicrograph showed a lower amount of glycogen in livers of this group (H\&E stain) PAS technique. Central vein $(\mathrm{CV})$.

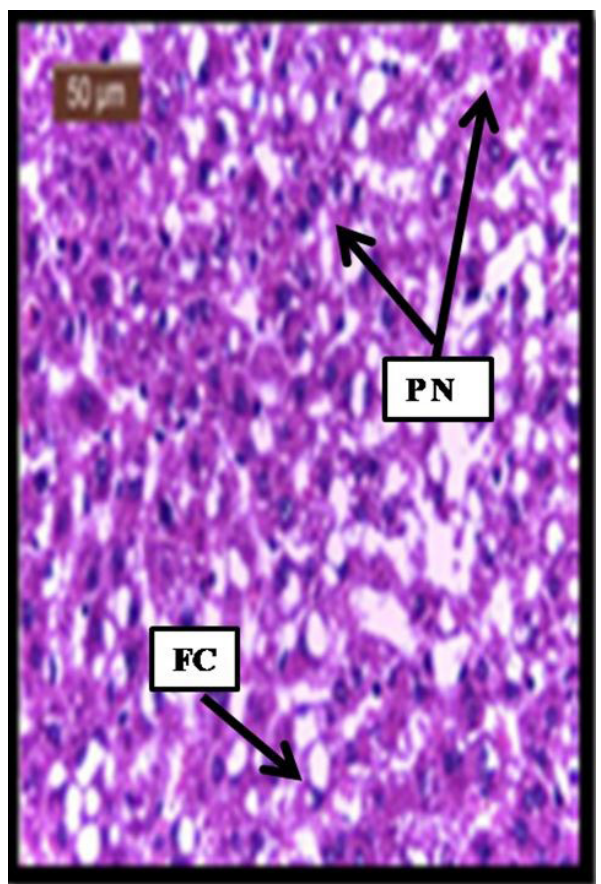

Figure 2. Photomicrograph of the liver of rat which feeds on wheat fumigated for 3 days showed some hepatocytes appeared as fat cells (FC) of empty cytoplasm with peripheral nuclei (PN) (H\&E stain).

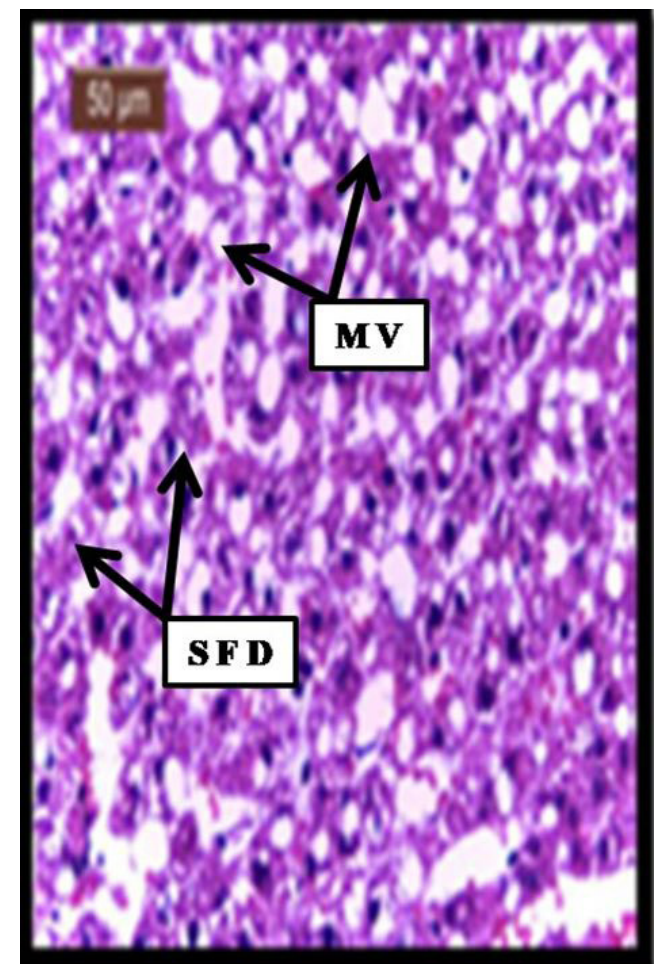

Figure 3. Photomicrograph of the liver of rat which feeds on wheat fumigated for 5 days showed many hepatocytes showing severe fatty degeneration (SFD) resulting in multiple vacuoles (MV) (H\&E stain).

At five days of treatment, the affected hepatocytes increased showing multiple large lipid vacuoles representing severe fatty degeneration while normal hepatocytes decreased (Figure 3). Because of the multiple vacuoles and empty cytoplasm, the glycogen content in livers of this group showed a lower amount in comparison to control liver.

\subsubsection{Kidney}

The histological section on the kidneys of rats which fed on non-fumigated wheat grains treatment, which showed renal tubules both Proximal tubule (PCT), Distal tubule (DCT), also Glomerula, Parietal layer, Visceral layer and Collecting tubule (Figure 4) the histological section on the kidneys in this group showed no histological abnormalities. In rat which was fed on fumigated wheat treatment for 3 days, some degenerative changes were noticed mainly fatty degeneration in renal tubules around glomerulus Figure 5. Concerning the rat feeding on fumigated wheat treatment for 5 days, the histological section on the kidneys showed moderate degenerative changes in renal tubules with degenerated material and desquamated cells in the lumen of tubules Figure 6.

\subsubsection{Stomach}

Photomicrograph of rat Stomach in control group showed no histological abnormalities, the mucous secreting cells were at the neck of glands only (Figure 7). While the 


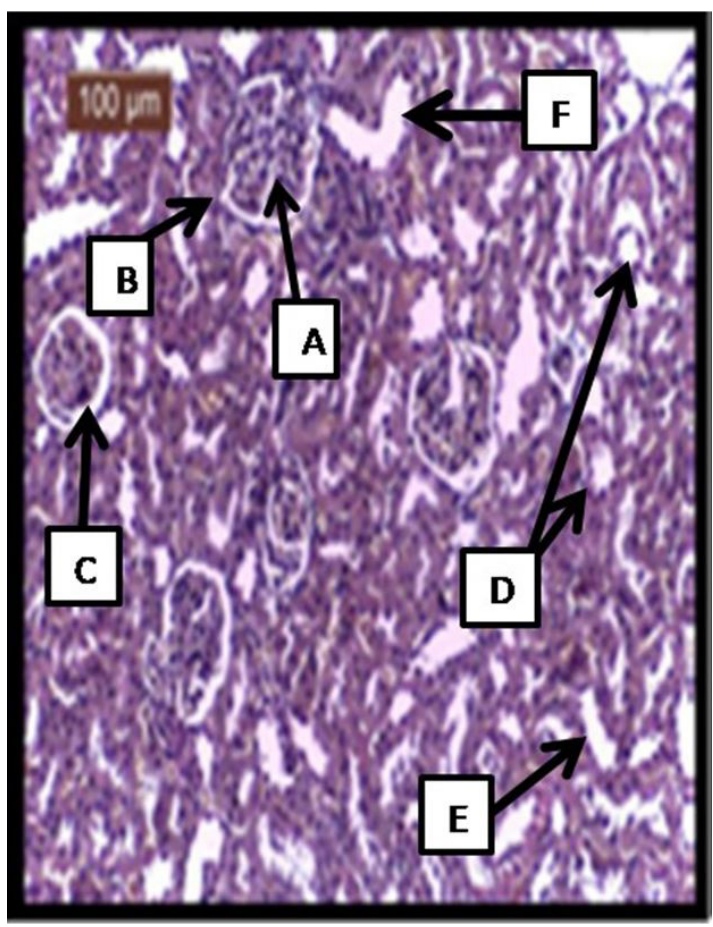

Figure 4. Photomicrograph of normal histological structure of kidney in control group which showed the glomeruli (A), Parietal layer (B), Visceral layer (C), Proximal tubule (D), Distal tubule (E) and Collecting tubule (F) Masson's trichrome stain.

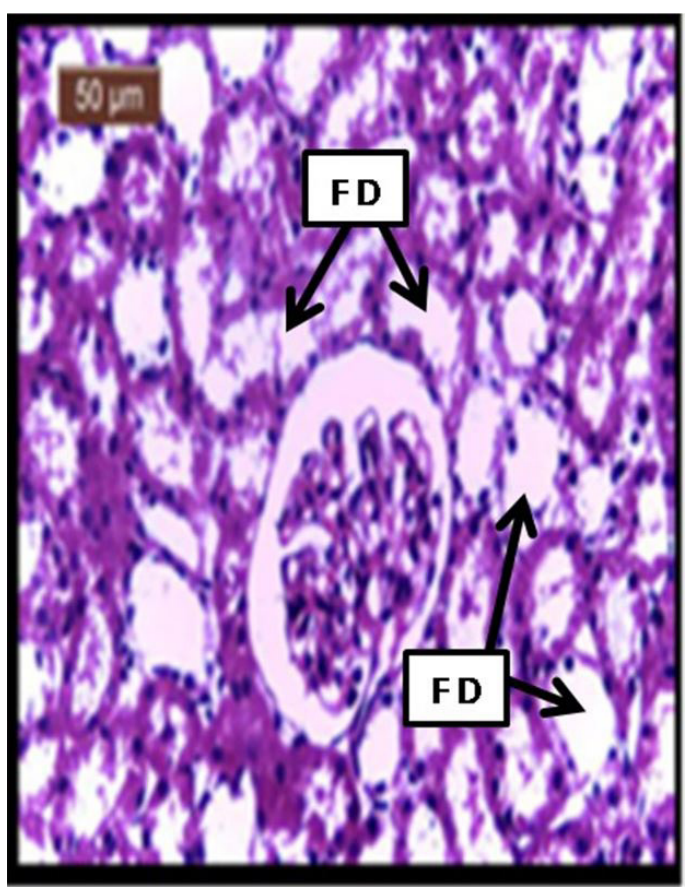

Figure 5. Photomicrograph of rat kidney which feeds on fumigated wheat treatment for 3 days showed degenerative changes mainly fatty degeneration (FD) in renal tubules around glomerulus (H\&E stain).

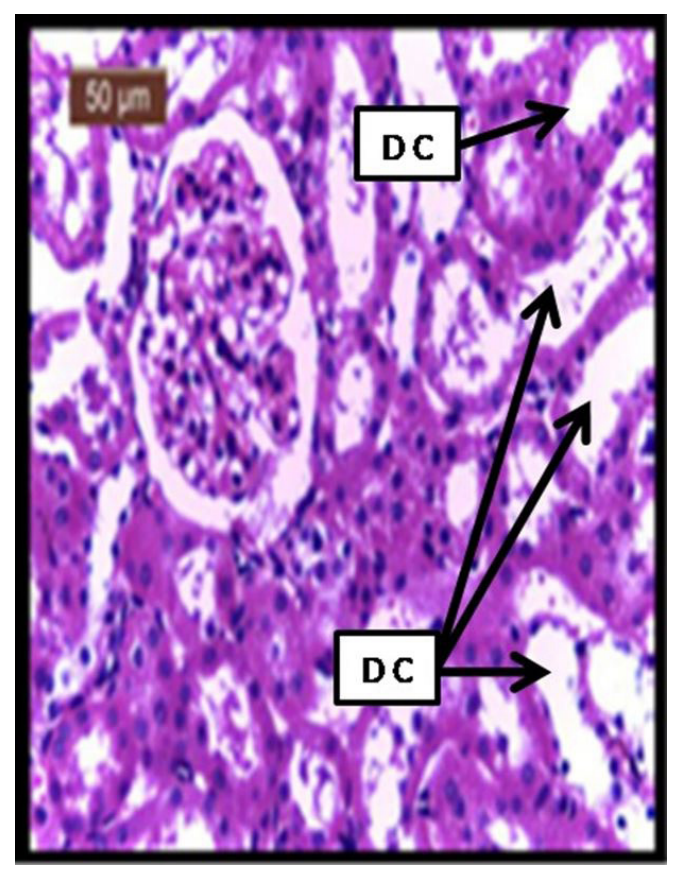

Figure 6. Photomicrograph of rat kidney which feeds on fumigated wheat treatment for 5 days showed degenerative changes in renal tubules with degenerated material and desquamated cells (DC) in the lumen of tubule (H\&E stain).

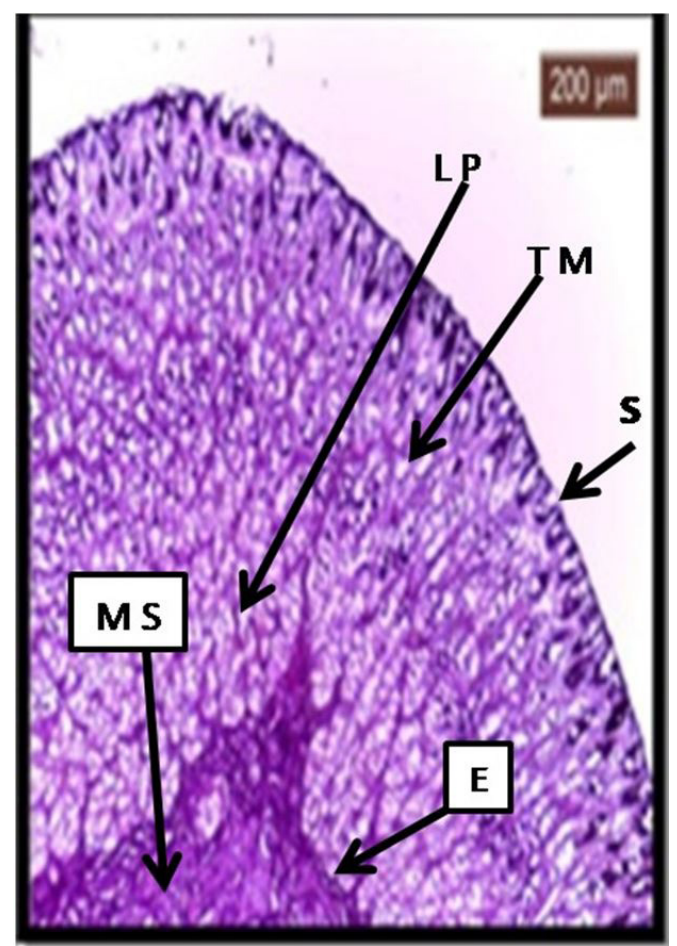

Figure 7. Photomicrograph of control stomach showed Serosa (S), Tunica muscularis (TM), Lamina propria (LP), Epithelium (E), and mucous secreting cells (MS) at the neck of glands only. PAS technique. 


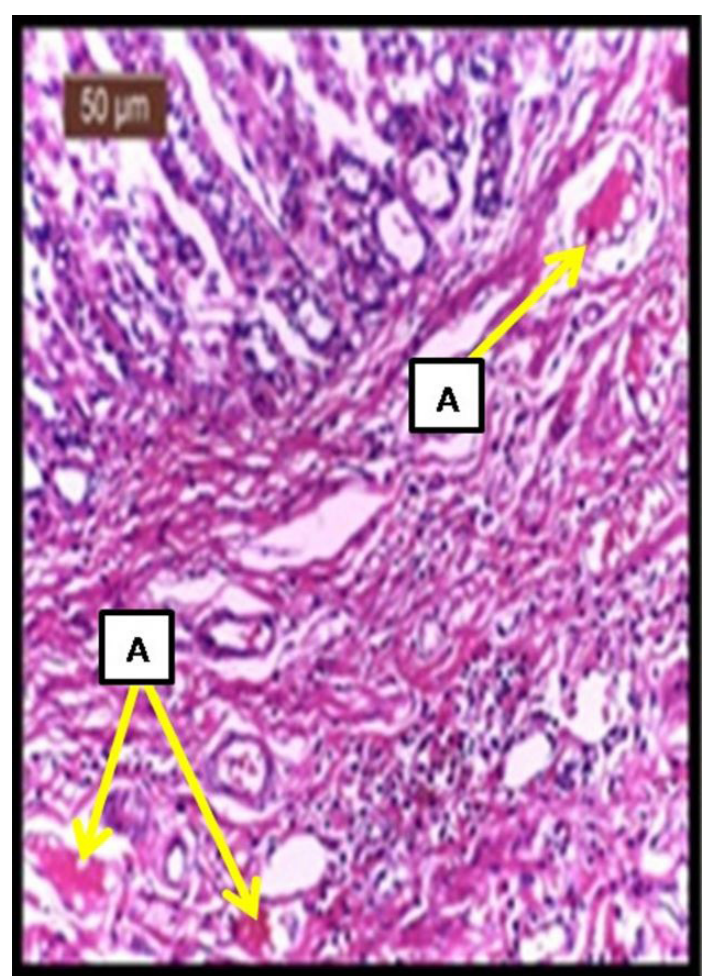

Figure 8. Photomicrograph of treated stomach showed a number of inflammatory mononuclear cellular infiltration (A) in submucosa just beneath the gastric glands (H\&E stain).

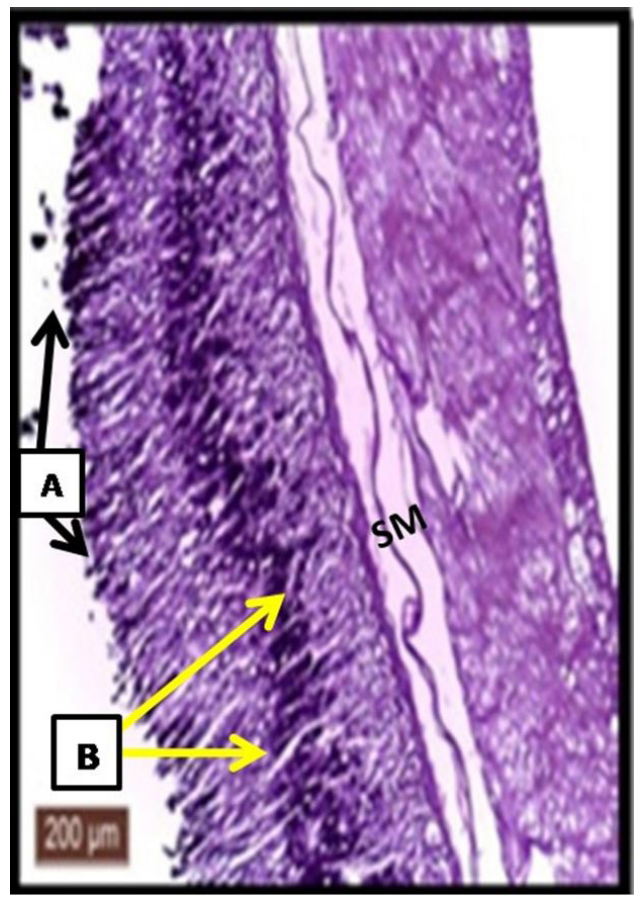

Figure 9. Photomicrograph of treated stomach showed Submucosa increase of mucous secreting cells that appeared in 2 levels; one was at the neck of glands (A) and the other was at the mid of glands (B). PAS-technique.
Stomach in the animals fed on fumigated wheat treatment for 3 days there is an increase of inflammatory mononuclear cellular infiltration in submucosa just beneath the gastric glands (Figure 8). Moreover, the stomach in the group which was fed on fumigated wheat treatment for 5 days showed an increase of mucous secreting cells which appeared in 2 levels; one was at the neck of glands and the other was at the mid of glands. These mucous secreting cells showed strongly PAS positive reaction (Figure 9). Although the fumigation with Garlic oil appeared to be safe in the 3-days exposure period, it exhibited some toxic effects in the 5-days exposure period of the study period. Where, the microscopic examinations of the different tissues (liver, kidney, and stomach) showed slightly changes especially, at the short exposure time. In the liver, mild to severe necrosis of the hepato cells of animals fed on fumigated wheat with the garlic oil was observed in this study. Necrosis of the liver has been reported by Sudakin and Power (2007) and Turkez and Togar (2013) who concluded that inhalation of phostoxin may cause severe pulmonary irritation leading to acute pulmonary edema, renal and hepatic damage. Disruption of the liver cell as reflected by the altered morphological structure is therefore suggested as the cause of raised serum level of liver enzymes as previously reported (Jimoh and Odutuga, 2001). It was reported that the phostoxin are causing activated signals lead to increase necrosis factors resulted inflammation, malignancy and cell death (Arora et al., 1995; Sinha et al., 2005; Saleki et al., 2007). In addition, Ozmen et al. (2009) and Mogilner et al. (2009) conducted the histological changes after exposure to $\mathrm{CO}_{2}$ as a result of hypoxia and/or ischemia that lead to acute cellular swelling, cytoplasmic vacuoles, hydropic degeneration, focal hemorrhage and epithelial cells within the tubular lumens. It could be concluded that the Garlic essential oil was the most effective oil to control T. castaneum based on the $\mathrm{LC}_{50}$ value.

And based on the histological findings Garlic essential oil was safe to protect the stored products as a fumigant, provided as a treatment of not more than 3-days.

\section{References}

ABBOTT, W.S., 1925. A method of computing the effectiveness of insecticide. Journal of Economic Entomology, vol. 18, no. 2, pp. 265-267. http://dx.doi.org/10.1093/jee/18.2.265a.

ARORA, B., PUNIA, R.S., KALRA, R., CHUGH, S.N. and ARORA, D.R., 1995. Histopathological changes in aluminium phosphide poisoning. Journal of the Indian Medical Association, vol. 93, no. 10, pp. 380-381. PMid:9053411.

AYVAZ, A., OZTURK, F., YARAY, K. and KARAHACIO, E., 2002. Effect of the gamma radiations and malathion on confused flour beetle, Tribolium confusum. J. du Val. Pakistan Journal of Biological Sciences, vol. 5, no. 5, pp. 560-562. http://dx.doi. org/10.3923/pjbs.2002.560.562.

BOEKE, S.J., BAUMGART, I.R., VAN LOON, J.J.A., VAN HUIS, A., DICKE, M. and KOSSOU, D.K., 2004. Toxicity and repellence of African plants traditionally used for the protection 
of stored cowpea against Callosobruschus maculatus. Journal of Stored Products Research, vol. 40, no. 4, pp. 423-438. http:// dx.doi.org/10.1016/S0022-474X(03)00046-8.

BOYER, S., ZHANG, H. and LEMPÉRIÈRE, G., 2012. A review of control methods and resistance mechanisms in storedproduct insects. Bulletin of Entomological Research, vol. 102, no. 2, pp. 213-229. http://dx.doi.org/10.1017/S0007485311000654. PMid:22126937.

DAGLISH, G.J., 2006. Survival and reproduction of Tribolium castaneum (Herbst), Rhyzoperthadominica (F.) and Sitophilus oryzae (L.) following periods of starvation. Journal of Stored Products Research, vol. 42, no. 3, pp. 328-338. http://dx.doi. org/10.1016/j.jspr.2005.04.003.

DANESHBAKHSH, D., ASGARPANAH, J., NAJAFIZADEH, P., RASTEGAR, T. and MOUSAVI, Z., 2018. Safety assessment of Mentha mozaffarianii assential oil: acute and repeated toxicity studies. Iranian Journal of Medical Sciences, vol. 43, no. 5, pp. 479-486. PMid:30214100.

DARWISH, A.A., SAFAA, M., EL-LAKWAH, F.A.M., EMAM, M.A. and EL-GIZAWY, K.K., 2015. Toxicity of carbon dioxide-phosphine combination to Tribolium castaneum inside gastight bins and its histological effect on albino rats. Annals of Agricultural Sciences, vol. 53, pp. 385-394.

EL-GIZAWY, K.K.H., 2012. Studies on effectiveness of some plant extracts and dusts against certain stored product insects. Benha, Egypt: Faculty of Agriculture, Banha University. M. Sc. Thesis.

FINNEY, D.J., 1971. Probit analysis. Cambridge: Cambridge University Press, $333 \mathrm{p}$

HUANG, Y., CHEN, S.X. and HO, S.H., 2000. Bioactivities of methyl allyl disulfide and diallyltrisulfide from essential oil of garlic to two species of stored-product pests, Sitophilus zeamais (Coleoptera: Curculionidae) and Tribolium castaneum (Coleoptera: Tenebrionidae). Journal of Economic Entomology, vol. 93, no. 2, pp. 537-543. http://dx.doi.org/10.1603/0022-0493-93.2.537. PMid:10826211

JACOBSON, M., 1990. Glossary of plant-derived insect deterrents. Boca Raton: CRC Press, 213 p.

JIMOH, F.O. and ODUTUGA, A.A., 2001. Changes in the activities of some diagnostic enzymes in some rat tissues following the consumption of thermally oxidized groundnut oil. Nigerian Journal of Biochemistry and Molecular Biology, vol. 16, pp. 173-176

KOUL, O., WALIA, S. and DHALIWAL, G.S., 2008. Essential oils as green pesticides: potential and constraints. Biopesticides International, vol. 4, no. 1, pp. 63-84

MOBKI, M., SAFAVI, S.A., SAFARALIZADEH, M.H. and PANAHI, O., 2014. Toxicity and repellency of garlic (Allium sativum L.) extract grown in Iran against Tribolium castaneum (Herbst) larvae and adults. Archiv für Phytopathologie und Pflanzenschutz, vol. 47, no. 1, pp. 59-68. http://dx.doi.org/10.10 80/03235408.2013.802896.

MOGILNER, J., SUKHOTNIK, I., BROD, V., HAYARI, L., CORAN, A.G.C., SHILONI, E., ELDAR, S. and BITTERMAN,
A., 2009. Effect of elevated intra-abdominal pressure on portal vein and superior mesenteric artery blood flow in a rat. Journal of Laparoendoscopic \& Advanced Surgical Techniques. Part A., vol. 19, suppl. 1, pp. 59-62. http://dx.doi.org/10.1089/lap.2008.0145. supp. PMid:19281420.

MONA, F., AZIZ, A.E. and SAYED, Y.A.E., 2009. Toxicity and biochemical efficacy of six essential oils against Tribolium confusum (Coleoptera: tenebrionidae). Egypt Academic Journal of Biological Sciences, vol. 2, no. 2, pp. 1-11.

MOSSA, A.-T.H., 2016. Green Pesticides: essential oils as biopesticides in insect-pest management. Journal of Environmental Science and Technology, vol. 9, no. 5, pp. 354-378. http://dx.doi. org/10.3923/jest.2016.354.378

MUNIZ, J.F., MCCAULEY, L., SCHERER, J., LASAREV, M., KOSHY, M., KOW, Y.W., NAZAR-STEWART, V. and KISBY, G.E., 2008. Biomarkers of oxidative stress and DNA damage in agricultural workers: a pilot study. Toxicology and Applied Pharmacology, vol. 227, no. 1, pp. 97-107. http://dx.doi. org/10.1016/j.taap.2007.10.027. PMid:18086483.

NOACK, S. and REICHMUTH, C.H., 1978. Einrechnerisches Verfahren Zur Bestimmung Von beliebigen Dosis-Werteneines Wirks to ffesausempirisch Dosis-wirkungs-Daten Mitt. Boil Bundesanstalt fur Land Forstwirtsch, Berlin Dahlem. Haft, vol. 185 , pp. 1-49.

OZMEN, M.M., ZULFIKAROGLU, B., BESLER, T.H., COL, C., CINEL, L. and CINEL, I., 2009. The correlation between reactive oxygen species and histopathology of the liver, gut, and kidneys in animals with elevated intra-abdominal pressure. Journal of Laparoendoscopic \& Advanced Surgical Techniques: Part A., vol. 19, no. 3, pp. 339-343. http://dx.doi.org/10.1089/ lap.2008.0293. PMid:19397391.

SALEKI, S., ARDALAN, F.A. and JAVIDAN-NEJAD, A., 2007. Liver histopathology of fatal phosphine poisoning. Forensic Science International, vol. 166, no. 2-3, pp. 190-193. http://dx.doi. org/10.1016/j.forsciint.2006.05.033. PMid:16806774.

SINHA, U.S., KAPOOR, A.K., SINGH, A.K., GUPTA, A. and MEHROTRA, R., 2005. Histopathological changes in cases of aluminium phosphide poisoning. Indian Journal of Pathology \& Microbiology, vol. 48, no. 2, pp. 177-180. PMid:16758658.

SUDAKIN, D.L. and POWER, L.E., 2007. Organophosphate exposures in the United States: a longitudinal analysis of incidents reported to poison centers. Journal of Toxicology and Environmental Health, vol. 70, no. 2, pp. 141-147.

TREMATERRA, P. and SCIARRETTA, A., 2004. Spatial distribution of some beetles infesting a feed mill with spatiotemporal dynamics of Oryzaephilus surinamensis, Tribolium castaneum and Tribolium confusum. Journal of Stored Products Research, vol. 40, no. 4, pp. 363-377. http://dx.doi.org/10.1016/ S0022-474X(03)00027-4

TÜRKEZ, H. and TOGAR, B., 2013. Aluminium phosphideinduced genetic and oxidative damages in vitro: attenuation by Laurus nobilis L. leaf extract. Indian Journal of Pharmacology, vol. 45, no. 1, pp. 71-75. http://dx.doi.org/10.4103/0253-7613.106439. PMid:23543905. 